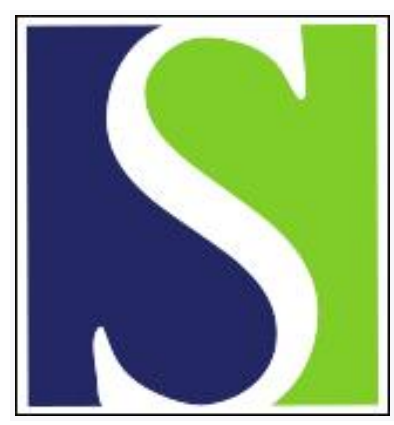

Scand J Work Environ Health 1987;13(6):505-512

https://doi.org/10.5271/sjweh.2012

Issue date: Dec 1987

\title{
Effects of exposure to vehicle exhaust on health.
}

by Ulfvarson U, Alexandersson R, Aringer L, Svensson E, Hedenstierna G, Hogstedt C, Holmberg B, Rosen G, Sorsa M

Affiliation: Royal Institute of Technology, Stockholm, Sweden.

This article in PubMed: www.ncbi.nlm.nih.gov/pubmed/2448871 


\title{
Effects of exposure to vehicle exhaust on health
}

\author{
by Ulf Ulfvarson, TechD, ${ }^{1}$ Rolf Alexandersson, MD, ${ }^{2}$ Leif Aringer, MD, ${ }^{3}$ Eva Svensson, MD, ${ }^{2}$ \\ Göran Hedenstierna, MD, ${ }^{4}$ Christer Hogstedt, MD, ${ }^{2,3}$ Bo Holmberg, PhD, ${ }^{3}$ Gunnar Rosén, ${ }^{3}$ \\ Marja Sorsa, $\mathrm{PhD}^{5}$
}

\begin{abstract}
ULFVARSON U, ALEXANDERSSON R, ARINGER L, SVENSSON E, HEDENSTIERNA G, HOGSTEDT C, HOLMBERG B, ROSÉN G, SORSA M. Effects of exposure to vehicle exhaust on health. Scand J Work Environ Health 13 (1987) 505-512. Exposure to combustion engine exhaust and its effect on crews of roll-on roll-off ships and car ferries and on bus garage staff were studied. The peak concentrations recorded for some of the substances studied were as follows: total particulates (diesel only) $1.0 \mathrm{mg} / \mathrm{m}^{3}$, benzene (diesel) $0.3 \mathrm{mg} / \mathrm{m}^{3}$, formaldehyde (gasoline and diesel) $0.8 \mathrm{mg} / \mathrm{m}^{3}$, and nitrogen dioxide (diesel) $1.2 \mathrm{mg} / \mathrm{m}^{3}$. The highest observed concentration of benzo(a)pyrene was $30 \mathrm{ng} / \mathrm{m}^{3}$ from gasoline and diesel exhaust. In an experimental study volunteers were exposed to diesel exhaust diluted with air to achieve a nitrogen dioxide concentration of $3.8 \mathrm{mg} / \mathrm{m}^{3}$. Pulmonary function was affected during a workday of occupational exposure to engine emissions, but it normalized after a few days with no exposure. The impairment of pulmonary function was judged to have no appreciable, adverse, short-term impact on individual work capacity. In the experimental exposure study, no effect on pulmonary function was observed. Analyses of urinary mutagenicity and thioether excretion showed no sign of exposure to genotoxic compounds among the occupationally exposed workers or among the subjects in the experimental study.
\end{abstract}

Key terms: engine exhaust, genotoxicity, mutagenicity, pulmonary function, thioethers.

The main emission products arising from the combustion of fuels in engines are water and carbon dioxide. Other components of vehicle exhaust are nitrogen and oxygen (in diesel exhaust), soot (mostly in diesel exhaust), a large number of hydrocarbons, and derivåtives of hydrocarbons with oxygen and nitrogen, along with carbon monoxide, oxides of nitrogen, and sulfur dioxide (in diesel exhaust). Their concentrations vary depending on many factors, eg, fuel composition, lubricant composition, engine design, operating temperature, load, degree of engine wear, fuel supply, condition of the system.

Occupations with the highest exposure to engine exhaust include mining; stevedoring; work around loading decks and quays; warehouse work with forklift trucks; loading motor vehicles onto car ferries; and work in bus garages, buildings at airports, parking garages, car-testing stations, and automobile repair shops.

The purpose of the present study was to investigate the acute effects of exposure to engine emissions on the respiratory tract. Furthermore, the mutagenicity method was applied to urine to test for exposures to

\footnotetext{
1 The Royal Institute of Technology, Stockholm, Sweden.

2 Department of Occupational Medicine, Karolinska Hospital, Stockholm, Sweden.

3 National Institute of Occupational Health, Solna, Sweden.

${ }^{4}$ Department of Clinical Physiology, Huddinge Hospital, Huddinge, Sweden.

5 Institute of Occupational Health, Helsinki, Finland.
}

Reprint requests to: Dr R Alexandersson, Department of Occupational Medicine, Karolinska Hospital, S-104 01 Stockholm, Sweden. the complex chemical mixtures contained in engine exhaust, since several earlier studies have shown that components in engine exhaust, especially the particulate fraction, are highly mutagenic in experimental systems $(28,29)$. A review of the literature relevant to this investigation has already been published (32).

\section{Subjects and methods}

Several workplaces producing comparatively heavy exposure, to diesel exhaust in particular, were chosen for the investigation. (See tables 1 and 2.) Occupational hygiene measurements were carried out at these workplaces, along with measurements of pulmonary function and genotoxic exposure. In addition, a small investigation with volunteers exposed to dilute engine emission was carried out in which the same occupational hygiene, medical, and toxicologic measurements were used as at the workplaces.

\section{Workplaces, job descriptions and measurement strategies}

Bus garage. In March-April a bus garage was investigated in which there were large and small dieselpowered vehicles and gasoline-driven buses used for transporting disabled persons. The work performed there, in addition to storage and engine warm-up, included refueling, washing and repairs. In the morning, afternoon, and evening elevated concentrations, in particular of diesel exhaust, accumulated in the garage bays when most buses left for or returned from assignments. The occupations represented were marshaler ( 2 workers), cleaner (1 worker), foreman ( 2 workers), 
Table 1. Characterization of the workers (men only) exposed to mixed exhaust (gasoline and diesel fumes) or to primarily diesel exhaust in the workplaces chosen for the investigation.

\begin{tabular}{|c|c|c|c|c|c|c|c|c|c|}
\hline \multirow{2}{*}{ Workplace } & \multicolumn{3}{|c|}{ Number of subjects } & \multicolumn{2}{|c|}{ Age (years) } & \multicolumn{2}{|c|}{ Height $(\mathrm{cm})$} & \multicolumn{2}{|c|}{ Weight $(\mathrm{kg})$} \\
\hline & Smokers & Nonsmokers & Total & Mean & SD & Mean & SD & Mean & SD \\
\hline \multicolumn{10}{|c|}{ Mixed exhaust } \\
\hline $\begin{array}{l}\text { Bus garage } \\
\text { Car ferries }\end{array}$ & $\begin{array}{r}5 \\
15\end{array}$ & $\begin{array}{l}12 \\
10\end{array}$ & $\begin{array}{l}17 \\
25\end{array}$ & $\begin{array}{l}32 \\
36\end{array}$ & $\begin{array}{l}10.3 \\
11.4\end{array}$ & $\begin{array}{l}180 \\
177\end{array}$ & $\begin{array}{l}7.6 \\
5.7\end{array}$ & $\begin{array}{l}80 \\
76\end{array}$ & $\begin{array}{r}9.2 \\
10.5\end{array}$ \\
\hline \multicolumn{10}{|c|}{ Diesel exhaust } \\
\hline II & $\begin{array}{l}12 \\
13\end{array}$ & $\begin{array}{l}11 \\
11\end{array}$ & $\begin{array}{l}23^{\mathrm{a}} \\
24^{\mathrm{a}}\end{array}$ & $\begin{array}{l}34 \\
36\end{array}$ & $\begin{array}{l}7.0 \\
6.3\end{array}$ & $\begin{array}{l}180 \\
181\end{array}$ & $\begin{array}{l}7.0 \\
7.0\end{array}$ & $\begin{array}{l}82 \\
81\end{array}$ & $\begin{array}{r}9.4 \\
11.0\end{array}$ \\
\hline
\end{tabular}

a Ten persons took part on both occasions at the ro-ro ships.

Table 2. Chemical characterization of the air samples, obtained with a personal sampling technique, from the workplaces and from the experimental study and the occupational exposure limits of the substances determined. The readings from the ro-ro ships are averages for a whole workshift. Other results represent the exposure measured for part of a day. In the latter instances the measurements were carried out during the course of work entailing exposure.

\begin{tabular}{|c|c|c|c|c|c|c|c|c|c|c|c|c|}
\hline & \multicolumn{12}{|c|}{ Range of the substances determined } \\
\hline & $\begin{array}{l}\text { Acetal- } \\
\text { dehyde } \\
\left(\mathrm{mg} / \mathrm{m}^{3}\right)\end{array}$ & $\begin{array}{l}\text { Benzo- } \\
\text { (a)pyrene } \\
\left.\text { (ng/m } / \mathrm{m}^{3}\right)\end{array}$ & $\begin{array}{l}\text { Benzene } \\
\left(\mathrm{mg} / \mathrm{m}^{3}\right)\end{array}$ & $\begin{array}{l}\text { Dust } \\
\left(\mathrm{mg} / \mathrm{m}^{3}\right)\end{array}$ & $\begin{array}{l}\text { Form- } \\
\text { aldehyde } \\
\left(\mathrm{mg} / \mathrm{m}^{3}\right)\end{array}$ & $\begin{array}{l}\text { Carbon } \\
\text { monoxide } \\
\left(\mathrm{mg} / \mathrm{m}^{3}\right)\end{array}$ & $\begin{array}{l}\text { Nitrogen } \\
\text { dioxide } \\
\left.\text { (mg/m } / m^{3}\right)\end{array}$ & $\begin{array}{l}\text { Nitrous } \\
\text { oxide } \\
\text { (mg/m } \mathrm{m}^{3} \text { ) }\end{array}$ & $\begin{array}{l}\text { Nitrous } \\
\text { acid } \\
\left(\mathrm{mg} / \mathrm{m}^{3}\right)\end{array}$ & $\begin{array}{l}\text { Sulfur } \\
\text { cioxide } \\
\left(\mathrm{mg} / \mathrm{m}^{3}\right)\end{array}$ & $\begin{array}{l}\text { Total } \\
\text { carbo- } \\
\text { hydrates } \\
\left(\mathrm{mg} / \mathrm{m}^{3}\right)\end{array}$ & $\begin{array}{l}\text { Toluene } \\
\left(\mathrm{mg} / \mathrm{m}^{3}\right)\end{array}$ \\
\hline Bus garage & $0.28-1.5$ & $<10$ & $\leq 0.2$ & $0.46^{\mathrm{b}}$ & $0.04-0.8$ & $1.7-24$ & $0.2-1.1$ & $0.3-1.0$ & $\cdots$ & $<1.8$ & $\cdots$ & $<0.2$ \\
\hline Car ferry (2-h run) & $0.49-1.5$ & $<10$ & $\leq 0.2$ & . & $0.03-0.31$ & $13-100$ & $<0.6$ & 0.06 & .. & $<1.8$ & . & $<0.2$ \\
\hline Car ferry (20-min run) & $1.02-2.1$ & $\leq 30$ & . & $0.1-0.3$ & $0.1-0.3$ & $5-190$ & $0.2-0.8$ & $0.2-1.0$ & $\cdots$ & . & $<190$ & . \\
\hline $\begin{array}{l}\text { Roll-on roll-off ships } \\
\text { IIc }^{c}\end{array}$ & $\begin{array}{l}<1.6 \\
\cdots\end{array}$ & $\begin{array}{l}. \\
\cdots\end{array}$ & $\begin{array}{c}\leq 0.3 \\
\cdots\end{array}$ & $\begin{array}{l}0.13-0.59 \\
0.3-1.0\end{array}$ & $\begin{array}{l}\leq 0.03 \\
0.1-0.5\end{array}$ & $\begin{array}{l}1.4-2.7 \\
1.1-5.1\end{array}$ & $\begin{array}{l}0.15-1.0 \\
0.06-2.3\end{array}$ & $\begin{array}{l}0.1-0.8 \\
0.02-0.7\end{array}$ & $\begin{array}{c}0.002-0.02 \\
\ldots\end{array}$ & $\begin{array}{ll}2 & \cdots \\
& \\
& .\end{array}$ & $\begin{array}{c}12-14 \\
. .\end{array}$ & $\begin{array}{c}<0.8 \\
\cdots\end{array}$ \\
\hline Experimental study & 0.3 & 0.64 & 0.2 & 0.6 & 0.05 & 5.3 & 3.9 & 5.6 & . & .. & . & 1.3 \\
\hline $\begin{array}{l}\text { Occupational exposur } \\
\text { limits } \\
\text { Ceiling }^{\mathrm{d}} \\
\text { Short-time value } \\
\text { Time-weighted } \\
\text { average limit }\end{array}$ & $\begin{array}{l}90 \\
45\end{array}$ & $\begin{array}{r}30000 \\
5000\end{array}$ & $\begin{array}{l}30 \\
16\end{array}$ & $\begin{array}{l}1 \\
\cdot \\
5^{a}\end{array}$ & 5 & $\begin{array}{l}120 \\
40\end{array}$ & $\begin{array}{l}10 \\
\cdot \\
4\end{array}$ & $\begin{array}{l}60 \\
30\end{array}$ & . & $\begin{array}{l}13 \\
5\end{array}$ & $\dot{.}$ & $\begin{array}{l}400 \\
300\end{array}$ \\
\hline
\end{tabular}

and mechanic (12 workers). Those responsible for the workplace had rated the ventilation as not fully satisfactory.

Car ferry. In June-July two types of car ferries were studied, one serving on a 2 -h route and the other on a 20 -min route. The job of the upper deck crew on the former was to direct vehicles to and from their parking places on the car deck. Loading and unloading averaged $20 \mathrm{~min}$. In the intervals between the loading and unloading, the deck crew performed other tasks. The first and second mates had duties on the bridge during crossings.

On the second type of ferry, work consisted of directing vehicles to the right place as they came aboard (so the maximum number of cars and lorries could be accommodated on the car deck) and assisting in the unloading of vehicles from the deck after the ferry had docked. Their work also included mooring the ferry. The mate's job was to lower the gangway after docking, check the tickets of passengers traveling in vehicles, and supervise operations while vehicles were driven on and off the car deck. Samples were only taken during the loading and unloading of vehicles.

Roll-on roll-off ships. The investigations aboard the roll-on roll-off (ro-ro) ships were carried out in January-February and in June and covered lower deck crew whose exposure to exhaust gas was judged to be the heaviest. During loading, cargo was moved from the quay onto the ship with large diesel-powered trucks. Once the cargo was on deck, smaller trucks took over and carried out the final stowage. The work of each truck driver was directed by one or two men on the deck. A supervisor was in charge of one or more decks. The truck drivers drove their trucks aboard ship and also spent a short time on deck. Drivers of the big trucks transferred cargo between the quay and the ships. They remained in their cabs the whole workday. One group, made up in part of supervisors, placed padding, etc, under cargo to keep it steady. The supervisors directed the loading and unloading of cargo. 
Experiments in the exposure chamber. Six workers were placed in an exposure chamber (interior dimensions $4.9 \times 2.9 \times 2.5 \mathrm{~m}$ ) into which exhaust gas, diluted with air, from a diesel-powered vehicle was piped. The dilution was adjusted so that the nitrogen dioxide in the chamber amounted to about $2 \mathrm{ppm}$.

The test vehicle was a 1980 Volvo 244D automobile with a manual, four-speed transmission. The vehicle was powered by a six-cylinder, precombustion chamber diesel engine $\left(2383 \mathrm{~cm}^{3}\right)$. The compression was $23: 1$, and the engine output $60 \mathrm{~kW}$. During the experiment the vehicle was run at a constant speed, equivalent to $60 \mathrm{k} / \mathrm{h}$ in third gear. This rate produced an engine speed of about 2580 revolutions $/ \mathrm{min}$. The engine load was calculated as $18 \mathrm{~kW}$ (maximum engine output about $35 \mathrm{~kW}$ at the indicated engine speed). This engine load is about four to five times higher than the load during driving on a dry, level road. The engine was kept running for $3 \mathrm{~h}$ and $40 \mathrm{~min}$ without interruption.

\section{Hygienic measurements and chemical analysis}

Total dust and respirable dust were collected on cellulose acetate filters in personal and stationary sampling equipment. The sampling of formaldehyde and acetaldehyde was performed with personal sampling equipment with chemosorption, and the samples were analyzed with high-performance liquid chromatography $(2,3)$. Hydrocarbons were collected in an aluminum laminate bag and then analyzed with a nonspecific, direct-reading photoionization detector (HNU PI 101). Some samples were taken with a carbon tube or Tenax ${ }^{(f)}$ tube and then analyzed with gas chromatography. Hydrocarbons were sampled with personal equipment only.

Both the personal and the stationary sampling was carried out for mass spectrometry determinations of benzo(a)pyrene and total polycyclic aromatic hydrocarbons (PAH). The particles were collected on glass fiber filters, whereas gas samples were collected by twostage chilling of the samples with water and dry ice and ethanol. The samples were analyzed with a mass spectrometer employing multiple ion detection (15).
Air was collected in an aluminum laminate bag and analyzed for carbon monoxide with a direct-reading instrument containing an electrochemical cell (Interscan 1144) and for nitric oxide and nitrogen dioxide with a direct-reading instrument (Monitor Labs 8440) according to the chemiluminescence principle. Sulfur dioxide was determined with a direct-reading instrument (Interscan) according to an electrochemical measuring principle. Nitrous acid and nitric acid were collected in glass tubes coated with sodium hydroxide. Subsequent analysis was carried out with ion-exchange chromatography (17).

Acetone extracts of the particulate component of three air samples from the exposure chamber experiment were analyzed for mutagenicity in the Ames test with two bacterial strains (Salmonella typhimurium, TA 98 and TA 100), both with and without metabolic activation (1).

\section{Biological methods}

Determination of urinary mutagenicity and urinary thioether excretion. Workers occupationally exposed to engine exhausts were asked to provide urine specimens (on a random basis) immediately before going to work (unexposed sample) and again at the end of or immediately after work (exposed sample). The urine specimens were immediately frozen and stored at $-20^{\circ} \mathrm{C}$ for several months.

The subjects in the experimental exposure supplied urine specimens before and at several times after the exposure (table 3). Since it has been found (5) that diet may have a powerful effect on the urinary excretion of thioethers and it can be assumed that certain drugs are capable of influencing thioether formation, dietary intake was standardized during the experimental day. In addition the subjects refrained from taking any medication. They carefully avoided certain vegetables (the cruciferae family such as cabbage and horseradish) which contain comparatively large amounts of thiocyanate $(5,37)$. The urine specimens were immediately frozen and stored at $-20^{\circ} \mathrm{C}$ for several months.

Table 3. Thioether concentration and mutagenic activity in the urine of six workers before and after the experimental exposure to diesel exhaust gases. ( $S E=$ standard error of the mean)

\begin{tabular}{|c|c|c|c|c|c|c|c|c|}
\hline & \multirow{2}{*}{\multicolumn{2}{|c|}{$\begin{array}{c}\text { Thioether } \\
\text { concentration } \\
\text { (mol/mol creatinine) }\end{array}$}} & \multicolumn{4}{|c|}{ Salmonella typhimurium TA 98} & \multirow{2}{*}{\multicolumn{2}{|c|}{$\begin{array}{c}\text { Escherichia coli } \\
\text { WP2 uvrA } \\
\text { + S-9 mix } \\
\text { (revertants/mol } \\
\text { creatinine) }\end{array}$}} \\
\hline & & & \multicolumn{2}{|c|}{$\begin{array}{c}+\mathrm{S}-9 \mathrm{mix} \\
\text { (revertants/ } \\
\text { mol creatinine) }\end{array}$} & \multicolumn{2}{|c|}{$\begin{array}{c}-\mathrm{S}-9 \mathrm{mix} \\
\text { (revertants/ } \\
\text { mol creatinine) }\end{array}$} & & \\
\hline & Mean & SE & Mean & SE & Mean & SE & Mean & SE \\
\hline Before exposure & 2.7 & 0.4 & $181^{\mathrm{a}}$ & 106 & 300 & 112 & $78^{\mathrm{b}}$ & 56 \\
\hline After exposure & 2.6 & 0.3 & 88 & 46 & 380 & 143 & 33 & 19 \\
\hline Four hours after exposure & 2.5 & 0.3 & 54 & 24 & 0 & . & 8 & 5 \\
\hline Eight hours after exposure & 2.7 & 0.3 & 153 & 64 & $\cdot$ & . & 18 & 8 \\
\hline Next morning & 2.3 & 0.2 & 170 & 51 & . & . & 9 & 6 \\
\hline
\end{tabular}

a One sample exceeded 600 .

b One sample exceeded 300 . 
Two bacterial strains were used for the determination of urinary mutagenicity, $S$ typhimurium TA 98 and Escherichia coli WP2 uvrA. The analyses were carried out at the Mutagen Laboratory of the Institute of Occupational Health, Helsinki, using the copolymer XAD-2 (for the determination of the concentrations in the urine specimens) and the fluctuation method $(16,38)$.

The urinary concentrations of the thioethers (13) were determined by spectrophotometry, using Ellman's reagent after hydrolysis to thiols according to the method described by van Doorn et al $(34,35)$.

All the exposed persons (see table 1) were examined with the use of spirometry and the single-breath nitrogen-washout technique. The subjects from the car ferries and bus garage were examined on a Monday after a 2-d break from work. Stevedores on the ro-ro ships were examined after a 10 -d break from work. All the exposed subjects were examined before they entered the work premises and after the workday. The exhaust concentrations in the air were determined with a personal sampling technique during the workday. On the basis of these results the study was expanded to include a second examination of the stevedores on the ro-ro ships on a later occasion. Prior to the examination, the stevedores were not exposed to exhaust gases for 5 or $6 \mathrm{~d}$. After exposure to emissions for 1 or $2 \mathrm{~d}$, the group was monitored during unexposed work so as to determine the time needed for pulmonary function to recover after deterioration.

Forced expired vital capacity was recorded with a low-resistance bellows spirometer (Ohio 740). At least two measurements were taken per person. The best result for each variable was chosen, even if the value had to be taken from different determinations, and the volumes were adjusted to conditions of body temperature and pressure saturated with water vapor (BTPS) (19).

The following variables were determined: forced vital capacity (FVC), forced expiratory volume in $1 \mathrm{~s}$ $\left(\mathrm{FEV}_{1.0}\right), \mathrm{FEV} \%\left[\left(100 \times \mathrm{FEV}_{1.0}\right) / \mathrm{FVC}\right]$, and maximal midexpiratory flow (MMF).

Reference values for the spirometric variables were taken from Berglund et al (9) and Birath et al (10).

Single-breath nitrogen washout (4) was studied with the use of the aforementioned bellows spirometer and a "bag-in-box" unit. The nitrogen concentration was measured with an analyzer operating on the ionization principle (Ohio 720). The gas concentration and volume were documented on an $\mathrm{x}-\mathrm{y}$ recorder (Bryans 26000). At least two measurements were taken at an interval of $7-10 \mathrm{~min}$. The closing volume (CV) was expressed as the percentage of expiratory vital capacity $(\mathrm{CV} \%)$. The slope of the alveolar plateau (phase III) was expressed as the percentage of nitrogen per liter of exhaled gas. The nitrogen washout data obtained in this manner were compared to reference values from Buist \& Ross $(11,12)$.
Linear regression analyses were performed in intraand interindividual comparisons between degree of exposure and lung-function effect. The two-tailed Student's t-test was used (30).

\section{Results}

\section{Exposure conditions}

An overview of the workplaces visited, the subjects, and the measured concentrations of substances can be found in tables 1 and 2.

The carbon monoxide peaks were lower in the bus garage (where diesel-powered vehicles were predominant) than on the ferries. The carbon monoxide concentrations were also low on the ro-ro ships on which only diesel trucks were used. The blood of exposed nonsmokers before and after a workshift displayed no increase in carboxyhemoglobin. The concentrations of nitrogen oxides were not higher than at the other workplaces where both gasoline- and diesel-powered vehicles were used.

At the concentrations tested, none of the three extracts from the filter samples was toxic to either strain of S typhimurium (TA 98 or TA 100), but extracts were mutagenic and produced a linear dose-response relationship. The maximal number of observed revertants per cubic meter of air sample was 643 for strain TA 100-S9. Mutagenicity was observed both with and without a rat-liver metabolic system (S-9 mix), but the response was slightly lower in both strains when metabolic activation was used.

\section{Urinary mutagenicity and urinary excretion of thioethers}

Occupationally exposed workers. Comparisons between the urinary mutagenicity of samples from an exposed and an unexposed period failed to disclose any significant differences between the number of revertants per mole of creatinine, ie, either in the occupationally exposed group as a whole or after the group had been divided into smokers and nonsmokers. A few samples displayed values that were barely above the limits regarded as mutagenic ( $>600$ for $S$ typhimurium and $>300$ for $E$ coli) (16). All but one of these urine specimens had been submitted by smokers. For the mutagenicity of the $S$ typhimurium strain TA 98 , the mean value for the smokers was higher than that of the nonsmokers [mean 231 (SE 58) and 197 (SE 54) revertants/mol of creatinine, respectively].

No significant differences in thioether excretion were found between the samples from the exposed and unexposed periods, ie, either in the occupationally exposed group as a whole or after the group had been divided into smokers and nonsmokers [5.8 (SE 0.5) and 5.5 (SE 0.5 ) $\mathrm{mmol} / \mathrm{mol}$, respectively]. If, on the other hand, all the samples from the smokers are compared to all the samples from the nonsmokers, the value of the smokers is significantly higher than that of the 
nonsmokers [7.2 (SE 0.6) and 4.7 (SE 0.4) $\mathrm{mmol} / \mathrm{mol}$, respectively, $P=0.001$.]

Experimental exposure. Neither the thioether findings nor any of the values obtained in the tests for urinary mutagenicity were increased after the experimental exposure to the diesel exhaust-air mixture. (See table 3.)

\section{Pulmonary function studies}

For each person, a comparison was made with the reference material on a Monday before work and after a break from work lasting at least $2 \mathrm{~d}$ (table 4). The exposed group displayed an average reduction of 0.331 in FVC $(P<0.001)$ and of $0.23 \mathrm{I}$ in $\mathrm{FEV}_{1.0}$ $(\mathrm{P}<0.005)$. There were no differences between the smokers and nonsmokers. There were no corresponding significant changes in the MMF, $\mathrm{CV} \%$, or phase III variables. As a further check for a possible correlation between exhaust exposure and pulmonary function, various linear regression analyses were used, but they failed to disclose any significant correlations.

The pulmonary function of all the exposed subjects was studied before and after a workday. The mean exposure on this day was as follows: nitric oxide $0.6 \mathrm{mg} / \mathrm{m}^{3}$, nitrogen dioxide $0.54 \mathrm{mg} / \mathrm{m}^{3}$, carbon monoxide $1.1 \mathrm{mg} / \mathrm{m}^{3}$, and formaldehyde $0.15 \mathrm{mg} / \mathrm{m}^{3}$. Significant impairment in pulmonary function was found (table 4). The FVC declined by an average of $0.15 \mathrm{l}$ and the $\mathrm{FEV}_{1.0}$ by a corresponding value of 0.11 . No changes were found in the MMF, the $\mathrm{CV} \%$, or the alveolar plateau gradient (phase III). There was no significant difference between the smokers and nonsmokers in pulmonary function on Monday before work.

The presence of any correlation between the exposure to various investigated components in exhaust gas and the investigated pulmonary function variables was studied. However, no correlation was found between the changes in pulmonary function and exposure to nitric oxide, nitrogen dioxide, or formaldehyde in comparison with either peak values or the mean values for the various components in the exhaust gases during one workshift. Nor was any correlation found between the changes in pulmonary function and the carbon monoxide concentration.

The group of stevedores who had only been exposed to diesel emissions on ro-ro ships had a 10-d break from exposure before the medical investigation. There was no difference between the values of this group and the reference values before the start of the workday (table 4). However, pulmonary function did display deterioration during a workshift. The deterioration averaged $0.44 \mathrm{I}$ for FVC and 0.301 for $\mathrm{FEV}_{1.0}$. There was no difference between the smokers and nonsmokers.

A new study was carried out on another group of stevedores $(\mathrm{N}=24)$ to ascertain whether the

Table 4. Spirometric and nitrogen wash-out data for the exposed subjects (according to type of exposure) on a Monday before work and after periods of $2,5,10$ and 13 days of no exposure and after 3 days of exposure. Reference values were matched with regard to sex, age and height $(8,10,11)$. (FVC $=$ forced vital capacity, FEV $10=$ forced expiratory volume in $1 \mathrm{~s}, \mathrm{FEV} \%=\left(100 \times \mathrm{FEV}_{1.0}\right) / \mathrm{FVC}, \mathrm{MMF}=$ maximal midexpiratory flow, $\mathrm{CV} \%$ = closing volume expressed as the percentage of expiratory vital capacity, Phase III = slope of the aveolar plateau, $\mathrm{N}_{2}=$ nitrogen)

\begin{tabular}{|c|c|c|c|c|c|c|c|c|c|c|c|c|c|}
\hline & \multirow{2}{*}{$\begin{array}{l}\text { Number } \\
\text { of } \\
\text { workers }\end{array}$} & \multicolumn{2}{|c|}{ FVC (I) } & \multicolumn{2}{|c|}{$\mathrm{FEV}_{1.0}(\mathrm{I})$} & \multicolumn{2}{|c|}{ FEV \% } & \multicolumn{2}{|c|}{ MMF (I/s) } & \multicolumn{2}{|c|}{ CV\% } & \multicolumn{2}{|c|}{$\begin{array}{l}\text { Phase III } \\
\left(\% \mathrm{~N}_{2} / I\right)\end{array}$} \\
\hline & & Mean & SE & Mean & SE & Mean & SE & Mean & SE & Mean & SE & Mean & SE \\
\hline \multicolumn{14}{|l|}{ All exhaust exposure } \\
\hline \multirow[t]{2}{*}{ Reference value } & $\cdot$ & 5.66 & 0.06 & 4.47 & 0.06 & 78.8 & 0.4 & 4.32 & 0.06 & 12.2 & 0.5 & 1.04 & 0.01 \\
\hline & \multicolumn{3}{|c|}{$\mathrm{P}<0.0001$} & \multicolumn{2}{|c|}{$P=\frac{1}{1}+005$} & \multicolumn{2}{|c|}{$P=\underset{1}{1}$} & & & & & & \\
\hline Monday before work & 65 & 5.32 & 0.11 & 4.24 & 0.10 & 79.7 & 0.9 & 4.42 & 0.16 & 12.9 & 0.8 & 1.13 & 0.07 \\
\hline Mixed exhaust exposure & 42 & & & & & & & & & & & & \\
\hline $\begin{array}{l}\text { Reference value } \\
\text { After } 2 \mathrm{~d} \text { of no exposure } \\
\text { Change during a shift }\end{array}$ & $\cdot \cdot$ & $\begin{aligned} & 5.62 \\
& 5.17^{\star \star} \\
+ & 0.01\end{aligned}$ & $\begin{array}{l}0.07 \\
0.14 \\
\cdot\end{array}$ & $\begin{array}{l}4.44 \\
4.10^{*} \\
0.00\end{array}$ & $\begin{array}{l}0.08 \\
0.11\end{array}$ & $\begin{array}{l}78.7 \\
80.7 \\
-0.1\end{array}$ & $\begin{array}{l}0.06 \\
0.18\end{array}$ & $\begin{array}{l}4.29 \\
4.30 \\
-0.10\end{array}$ & $\begin{array}{l}0.08 \\
0.18\end{array}$ & $\begin{array}{l}11.8 \\
12.5 \\
+0.7\end{array}$ & $\begin{array}{l}0.8 \\
1.1 \\
\cdot\end{array}$ & $\begin{array}{l}1.02 \\
1.00 \\
-0.12\end{array}$ & $\begin{array}{l}0.02 \\
0.08 \\
-\end{array}$ \\
\hline \multicolumn{14}{|l|}{ Diesel exhaust exposure } \\
\hline \multirow{5}{*}{$\begin{array}{l}\text { Reference value } \\
\text { After } 10 \mathrm{~d} \text { of no exposure } \\
\text { Change during a shift } \\
\text { after } 10 \mathrm{~d} \text { of no exposure } \\
\text { Change during a shift } \\
\text { after } 5 \mathrm{~d} \text { of no exposure } \\
\text { Change from the values } \\
\text { measured after the shift } \\
\text { following } 5 \mathrm{~d} \text { of no } \\
\text { exposure after } 3 \mathrm{~d} \text { of } \\
\text { recovery (no exposure) }\end{array}$} & $\cdot$ & 5.72 & 0.18 & 4.53 & 0.10 & 79.13 & 0.6 & 4.38 & 0.00 & 12.2 & 0.7 & 1.04 & 0.02 \\
\hline & 23 & 5.62 & 0.16 & 4.50 & 0.17 & 79.8 & 1.4 & 4.65 & 0.30 & 13.2 & 1.3 & 1.27 & 1.22 \\
\hline & 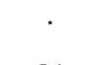 & $-0.44^{*}$ & . & $-0.30^{* *}$ & * $\cdot$ & +1.0 & $\cdot$ & -0.33 & $\cdot$ & 0.10 & · & +0.12 & $\cdot$ \\
\hline & 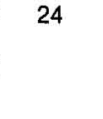 & $-0.16^{\star}$ & . & +0.02 & $\cdot$ & $+2.5^{\star}$ & $\cdot$ & +0.23 & $\cdot$ & 0.00 & $\cdot$ & 0.00 & $\cdot$ \\
\hline & $\cdot$ & $+0.24^{* *}$ & * & +0.13 & $\cdot$ & $-0.8^{*}$ & $\cdot$ & +0.04 & · & 0.00 & . & 0.00 & . \\
\hline
\end{tabular}

a Study occasion 1.

b Study occasion 2 ( 10 of these subjects took part in both investigations).

${ }^{*} \mathrm{P} \leq 0.01,{ }^{*} \mathrm{P} \leq 0.001$ (Student's two-sided $\mathrm{t}$-test). 
"acute" deterioration in pulmonary function found in the stevedores during one workshift was reproducible and, if so, how long any normalization would take. On this occasion exposure conditions were about the same as in the first investigation series (table 2). In this case, the break in exposure prior to the investigation was 5 to $6 \mathrm{~d}$. As in the first investigation, no significantly impaired pulmonary function was found before the workshift. But acute deterioration was recorded for FVC (which averaged $0.16 \mathrm{l}$ ) during one workday. This decline was accompanied by an increase in FEV\%. As table 4 shows, this decline in pulmonary function normalized after a 3-d break from exposure.

Ferry and garage personnel exposed to both gasoline and diesel exhaust had a 2-d break from exposure before the measurement of pulmonary function began before work on Monday. A decline in pulmonary function was found in this group $(0.451$ for FVC and 0.341 for $\mathrm{FEV}_{1.0}$ ) in comparison to the reference values (table 4). No additional deterioration was found in the pulmonary function during a workshift.

\section{Discussion}

\section{Exposure conditions}

In the experimental study the nitrogen oxide concentrations were generally higher than any peak concentration found at the workplaces at which only diesel engines were used (table 2). The concentrations of carbon monoxide were comparable with the peak concentrations found at the workplaces using diesel engines.

The total concentration of particulate-bound and gaseous PAH was $638 \mathrm{ng} /{ }^{3}$ in the exposure chamber.

The low molecular-weight compounds (methyl phenanthrenes, anthracenes, and phenanthrene) accounted for $76 \%$ of the total PAH content.

\section{Genotoxicity}

The particulate extract of the air samples from the exposure chamber displayed clear genotoxicity with a linear dose-response in the Ames test. Both test strains used, ie, Styphimurium TA 98 and TA 100 , yielded a higher response when no exogenous metabolic system was used. This finding points to the presence of direct-acting mutagenic substances [eg, nitroarenes such as 1-nitropyrene $(28,29)]$ characteristically found in diesel exhaust.

The ambient air samples taken from the exposure chamber during the voluntary exposure experiment and several previous studies performed on engine exhaust have all shown these emissions to be mutagenic, irrespective of the fuel type $(14,15,22,23,26,28,29)$. However no mutagens were found in the urine specimens of our subjects occupationally or experimentally exposed to vehicle emissions.

The negative results of the mutagenicity analysis of the urine do not preclude the absorption of mutagenic substances from engine exhaust. Several earlier studies $(31,38)$ have shown the test strain $S$ typhimurium TA 98, with metabolic activation ( $\mathrm{S}-9 \mathrm{mix}$ ) to be sensitive to tobacco smoke. The smokers in the present study also displayed greater mutagenic activity than the nonsmokers.

The excretion of thioethers in urine was similar before and after exposure to engine exhaust. On the other hand, the values of the smokers were significantly higher $(P=0.001)$ than those of the nonsmokers. This finding agrees with results reported earlier $(5,33)$. The individual results for the occupationally exposed subjects (some values exceeding $10 \mathrm{mmol} / \mathrm{mol}$ of creatinine in samples taken before exposure but declining in those taken after exposure) indicate that factors unrelated to the work environment, ie, probably dietary factors $(5,37)$ or possibly medication, had affected the results obtained for certain individuals in this group. The lower thioether levels and the lower variation in the values obtained in the experimental study, compared to the values of the occupationally exposed persons, might be due to the diet standardization employed in the experimental study.

The negative results of the urinary assays do not preclude the possibility that exhaust exposures may cause local mutagenic effects in, eg, lungs and airways, the regional lymph system, or the gastrointestinal tract, after exhaust particles are swallowed. Compounds excreted in bile were not detectable with the urinary assay methods used.

\section{Respiratory effects}

Exposure to exhaust fumes appeared to impair pulmonary function. These effects were found on a Monday morning, before work began, after cessation of exposure for at least $2 \mathrm{~d}$ and were accentuated during a workday with exposure to exhaust fumes.

The subjects comprised stevedores exposed only to exhaust from diesel-powered trucks and ferry and garage personnel exposed to both diesel and gasoline exhaust fumes. The stevedores had had a 10 -d break from exposure before the investigation started and displayed normal pulmonary function on the Monday before going to work as compared with the reference material. However, both their FVC and FEV 1.0 values deteriorated during a workday with exposure to exhaust. Similar but less pronounced effects were found in a second, subsequent study. Pulmonary function returned to normal after $3 \mathrm{~d}$ without occupational exposure to exhaust fumes.

The recovery to normal function after three exposure-free days may explain why the stevedore group did not display poorer pulmonary function than the reference group before exposure. This finding is consistent with the fact that no chronic lung effects solely attributable to exhaust gases and particles have been discernible in various cross-sectional studies of persons exposed to diesel exhaust $(6,7,8,18,24)$. 
After a 2-d break in exposure, the ferry and garage personnel exposed to mixed exhausts displayed a deterioration in pulmonary function of the same nature and magnitude as the stevedores after work. The functional deterioration showed no progression after one workday. Thus the same degree of dysfunction was observed in both the stevedores exposed solely to diesel exhaust and in the ferry and garage workers exposed to mixed exhaust emissions. These findings suggest that subjects who display functional deterioration after previous exposure to exhaust gases may not display any additional deterioration after renewed acute exposure and that subjects who have time to recover during a break from exposure may display acute deterioration. However, the interpretation of these findings is complicated by the differences in the exposure of the stevedores and that of the exposure of ferry and garage personnel and by the fact that no dose-related correlation was found between any irritating substances in the exhaust gases (nitric oxide, nitrogen dioxide, and formaldehyde) and an effect on pulmonary function. Nor was any correlation found with the carbonmonoxide exposure, investigated as a possible indicator of exposure to all exhaust compounds.

A decline of up to 0.41 in the FVC during a workday corresponded to a deviation of less than $10 \%$ from prework values. Smaller differences were found for the other variables. Presumably, these changes do not produce any discernible impairment in physical work capacity during moderate physical exertion, but they are a disturbing finding in a cross-sectional study since their prognostic implications are unknown.

The occupational exhaust exposure levels measured are among the highest in Sweden, and they appear to affect pulmonary function during a workday but cause relatively few subjective symptoms. This decline, which is reproducible in repeated measurements, normalizes after a few days without exposure to exhaust emissions. The changes are relatively slight and need not have any significant effect on physical work capacity. Because the changes are small, the nature of the dysfunction is difficult to assess. The decrease in FVC and $\mathrm{FEV}_{1.0}$, but not in FEV\% or MMF, like the virtually normal, single-breath nitrogen washout findings, may suggest a restrictive rather than an obstructive dysfunction, or a combination of both.

\section{Possible indicators of exhaust exposure}

In group studies, formaldehyde at concentrations of $0.40 \mathrm{mg} / \mathrm{m}^{3}$ in the air has been shown to be capable of affecting pulmonary function, ie, causing mainly obstruction. Formaldehyde alone, at concentrations down to $0.05 \mathrm{ppm}\left(0.06 \mathrm{mg} / \mathrm{m}^{3}\right)$, irritates the nose, eyes, and throat of sensitive people and produces discomfort at somewhat lower concentrations $(25,39)$. It is possible that aldehydes could explain some of the airway symptoms found in the present study. The levels were relatively low, and a higher incidence of eye, nose, and throat symptoms might have been expected.
High concentrations of nitrogen dioxide are known to cause acute effects on the lungs (20). Nitrogen dioxide produced increased respiratory resistance after a $15-\mathrm{min}$ exposure in the $1.6-2.0 \mathrm{ppm}$ (3.6$\left.2.9 \mathrm{mg} / \mathrm{m}^{3}\right)$ concentration range. Lower concentrations produce nasal irritation and laryngitic symptoms but no changes in lung physiology (21).

It should be pointed out that the alveolar concentration of several of the gases may be even higher than concentrations in the breathing zone, since additional input of injurious agents could conceivably occur by adsorption onto the soot particles present in exhaust emissions. The particulate phase in diesel exhaust resembles carbon black, since the particulate matter consists of more than $85 \%$ elementary carbon in the form of nearly spherical particles formed in the partial combustion of hydrocarbons. Diesel particles and carbon black particles are almost always respirable (36). A calculation assuming adsorption of a monomolecular layer of nitrogen dioxide on a dieșel aerosol indicates that the surface area of aerosol particles is sufficient to permit the particle-bonded nitrogen dioxide to constitute a substantial proportion of the total nitrogen dioxide concentration.

In summary published data on the effects of the substances studied at different concentrations and on measured concentrations of these substances in occupational exhaust exposure do not rule out the possibility that nitrogen dioxide and formaldehyde, or both, may give rise to effects on lung and mucous membranes at the concentrations found in practice.

\section{Acknowledgments}

The project received financial support from special project funds held by the National Board of Occupational Safety and Health.

\section{References}

1. Ames BN, McCann J, Yamasaki E. Methods for detecting carcinogens and mutagens with the Salmonella mammalian microsome test. Mutat Res 31 (1975) 347.

2. Andersson $\mathrm{K}$, Hallgren $\mathrm{C}$, Levin $\mathrm{J}-\mathrm{O}$, Nilsson C-A. Solid chemosorbent for sampling sub-ppm levels of actrolein and glutaraldehyde in air. Chemosphere 10 (1981): 3, 275--280.

3. Andersson $\mathrm{K}$, Hallgren $\mathrm{C}$, Levin $\mathrm{J}-\mathrm{O}$, Nilsson C-A. Chemosorption sampling and analysis of formaldehyde in air. Scand J Work Environ Health 7 (1981) 282-289.

4. Antonisen NR. Report of international session on "closing volume" determinations. National Heart Lung Institute. Bethesda, MD 1972.

5. Aringer L, Hogstedt C, Lidums V, Svensson E, Wrange R. Evaluation of some factors affecting determination of thioethers in urine. In: Institute of Occupational Health. International seminar on methods of monitoring human exposure to carcinogenic and mutagenic agents, 12-15 Dec 1983. Helsinki 1983, p 37. (Abstract).

6. Attfield MD. The effect of exposure of silica and diesel exhaust in underground metal and nonmetal miners. In: American Conference of Governmental Industrial Hygienists. ACGIH conference on mining and tunneling. 
Denver, CO 1978, pp 129-135.

7. Attfield MD, Trabant GD, Wheeler RW. Exposure to diesel fumes and dust at six potash mines. National Institute for Occupational Safety and Health, Morgantown, WV, and MSHA, Denver, CO 1980, pp 1-19.

8. Battigelli MC, Mannella RJ, Hatch TF. Environmental and clinical investigation of workmen exposed to diesel exhaust in railroad engine houses. Ind Med Surg 33 (1964) $121-124$.

9. Berglund E, Birath G, Bjure J, Grimby G, Kjellmer I, Sandqvist L, Söderholm B. Spirometric studies in normal subjects. Acta Med Scand 173 (1963) 185-189.

10. Birath G, Kjellmer J, Sandqvist L. Spirometric studies in normal subjects: II Ventilatory capacity tests in adults. Acta Med Scand 183 (1963) 193-198.

11. Buist AS, Ross BB. Predicted values for closing volumes using a modified single breath nitrogen test. Am Rev Respir Dis 107 (1973) 744-752.

12. Buist AS, Ross BB. Quantitative analysis of the alveolar plateau in the diagnosis of early airway obstruction. Am Rev Respir Dis 108 (1973) 1078-1087.

13. Chasseaud LF. The role of glutathione and glutathioneS-transferase in the metabolism of chemical carcinogenic and other electrophilic agents. In: Klein Y, Weinhouse $\mathrm{S}$, ed. Advance in cancer research. Academic Press, New York, NY 1979, pp 175-255.

14. Egebäck K-E, Ahlsberg T, Westerholm R, Rannug U, Winqvist L. Exposure chamber experiment with diesel exhausts: Generation of exhausts, concentrations of polyaromatic hydrocarbons and mutagenicity in air samples [In Swedish]. Technical unit, Research Department, Swedish National Board of Occupational Safety and Health, Solna 1984.

15. Egebäck K-E, Telje G, Stenberg U, Westerholm R, Alsberg T, Rannug U, Sundvall A. A comparative study of diluted and undiluted automobile exhaust utilizing polynuclear aromatic hydrocarbons analysis and mutagenicity tests. Central Institute for Industrial Research, Oslo 1981, pp 1-25. (Nordic PAH project report no 13).

16. Falck K. Application of the bacterial urinary mutagenicity assay in detection of exposure to genotoxic chemicals. Institute of Occupational Health, Helsinki 1982. (Doctoral dissertation).

17. Ferm M, Sjödin A. A simple method for determining of gaseous nitrous acid in the atmosphere. Swedish Environmental Research Institute, Göteborg 1983. (Publ no B 718).

18. Gamble J, Jones W, Hudak J. An epidemiological study of salt miners in diesel and non diesel miners. Am $\mathbf{J}$ Ind Med 4 (1983) 435-458.

19. Gardner RM. ATS statement-snowbird workshop on standardization of spirometry. Am Rev Respir Dis 119 (1979) 31-38.

20. Green FHY, Boyd RL, Danner-Rabovsky J, Fisher MJ, Moorman WJ, Ong TM, Tucker J, Vallyathan V, Whong W-Z, Zoldak J, Lewis T. Inhalation studies of diesel exhaust and coal dust in rats. Scand J Work Environ Health 9 (1983) 181-188.

21. Grenquist-Nordén B. Nordiska expertgruppen för gransvärdesdokumentation: 45. Nitrösa gases [Nordic Expert Group for the Documentation of Occupational Exposure Limits: 45. Nitrogen oxides]. Arbetarskyddsverket, Stockholm 1983. (Arbete och hälsa 1983: 28). (English abstract).

22. Holmberg B, Ahlborg U. Consensus report: Mutagenicity and carcinogenicity of car exhaust and coal combustion emissions. Environ Health Perspect 47 (1983) $1-28$.

23. Huisingh JL, Bradow R, Jungers R, Claxton L, Zwei- dinger R, Tejada S, Bumgarner J, Duffield F, Waters M, Simmon VF, Hare C, Rodriquez C, Snow L. Application of bioassay to the characterization of diesel particle emissions. In: Waters MD, Nesnow S, Huisingh JL, Sandhu SS, Claxton L, ed. Application of short-term bioassays in the 20-fractionation and analysis of complex environmental mixtures. Plenum Press, New York, NY 1978, pp 383-418.

24. Jörgensen $\mathrm{H}$, Swensson A. Studies on pulmonary function and respiratory tract symptoms of workers in an iron-mine ore where diesel trucks are used underground. J Occup Med 12 (1979) 348-354.

25. Kolmodin-Hedman B, Nordman H. Formaldehyde. Nordic Expert Group for Documentation of Occupational Exposure Limits [In Swedish]. Arbetarskyddsverket, Stockholm 1982. (Arbete och hälsa 1982: 27). (English abstract).

26. Lewtas J. Evaluation of the mutagenicity and carcinogenicity of motor vehicle emissions using short-term bioassays. Environ Health Perspect 47 (1983) 141-152.

27. National Board of Occupational Safety and Health Hygienic limit values. Stockholm 1984. (AFS 1984: 5).

28. Rannug U. Data from short-term tests on motor vehicle exhausts. Environ Health Perspect 47 (1983) 161-170.

29. Rosenkranz HS. Mutagenic and carcinogenic nitroarenes in diesel emissions: Risk identification. Mutat Res 140 (1984) $1-6$.

30. Snedcor GW, Coltrow WG. Statistical methods. 6th Iowa State University Press, Ames, IA 1967.

31. Sorsa M, Falck K, Heinonen T, Vainio H, Norppa H, Rimpelä M. Detection of exposure to mutagenic compounds in low-tar and medium-tar cigarette smokers. Environ Res 33 (1984) 312-321.

32. Ulfvarson $U$, Alexandersson $R$, Aringer $L$, AnshelmOlson B, Einistö P, Ekholm U, Hedenstierna G, Hogstedt C, Holmberg B, Lindstedt G, Randma E, Rosén G, Sorsa M, Svensson E. Hälsoeffekter vid exponering för motoravgaser [Health effects of exposure to motor exhaust gases]. Arbetarskyddsverket, Stockholm 1985. (Arbete och hälsa 1985: 5). (English summary).

33. Van Doorn R, Bos RP, Leijdekkers C-M, WagenaasZegers MAP, Theuws JLG, Henderson PT. Thioether concentration and mutagenicity of urine from cigarette smokers. Int Arch Occup Environ Health 43 (1979) $159-166$.

34. Van Doorn R, Leijdekker C-M, Bos RP, Brouns RME, Henderson PT. Detection of human exposure to electrophilic compounds by assay of thioether detoxication products in urine. Ann Occup Hyg 24 (1981) 77-92.

35. Van Doorn R, Leijdekker C-M, Bos RP, Brouns RME, Henderson PT. Enchanged excretion of thioeters in urine of operators of chemical waste incinerators. $\mathrm{Br} \mathrm{J}$ Ind Med 38 (1981) 187-190.

36. Willeke K, ed. Generation of aerosols and facilities for exposure experiments. Ann Arbor Science Publications Inc, Ann Arbor, MI 1980, pp 1-597.

37. Wood JL. Biochemistry: Plants. In: Newman AA, ed. Chemistry and biochemistry of thiocyanic acid and its derivatives. Academic Press, London 1975, pp 157-162.

38. Yamasaki E, Ames BN. Concentration of mutagens from urine by adsorption with the non-polar resin XAD-2: Cigarette smokers have mutagenic urine. Proc Natl Acad Sci USA 74 (1977) 3555-3559.

39. aldehyde. Environ Health Perspect 58 (1984) 323-380.

Received for publication: 2 January 1986 